\title{
LIABILITY OF HOSPITAL FOR INJURIES TO PATIENTS USING HOSPITAL FACILITIES
}

A PATIENT injured while receiving medical treatment in a hospital often seeks redress from the hospital as well as from the immediate tortfeasor. In addition to the usual subjects of inquiry in tort suits, courts are accustomed to consider both the character of the hospital and the functional relationship to the hospital of the perpetrator of the injury. Hospitals are commonly either privately conducted for profit, charitable, public, or industrial. ${ }^{1}$ Besides employing a resident staff of physicians, surgeons, specialists and nurses, many hospitals extend the privileges of the institution to independent doctors and nurses who wish to attend private patients there. Charitable and public hospitals have, in addition, an active visiting staff appointed primarily to care for the indigent sick. ${ }^{2}$ On the basis of these factual variations in hospital organization, the courts have assembled a complicated catalogue of classification and sub-classification. The question of compensation for an injured patient is more often answered by perfunctory reference to this card index system than by practical resolution of two obviously competing public needs. Rules of liability should be framed to assure competent medical care, and yet the development of hospital facilities must not be discouraged. On the basis of these two considerations, this Comment will appraise the existing rules of hospital liability for the torts of medical and nursing staffs.

Private hospitals conducted for profit are subject to the same standards of legal liability as other business enterprises. As a result, these establishments are usually held liable under the doctrine of respondeat superior for torts committed by resident physicians and nurses, however carefully the

1. Private hospitals for profit are organized and operated by the owners as regular business enterprises. See Lapp and Ketchaar, Hospital LAW (1926) 37. The purpose of charitable hospitals is to care for the sick among either particular groups or the public generally, by means of funds acquired principally through charitable contributions and sometimes also from patients. Id. at 24. See Powers v. MIassachusetts Homeopathic Hospital, 109 Fed. 294, 295 (C. C. A. 1st, 1901) ; MIcInerny v. St. Lulie's Hospital Association, 122 Minn. 10, 13, 141 N.W. 837, 838 (1913). A public hospital is owned, managed and controlled exclusively by some governmental unit for members of the general public. LAPP AND KeTCHAar, Hospital LAw (1926) 16. Industrial hospitals are organized by cmployers for the benefit of employees and are operated either as a charity or for the profit of the employer. See Union Pacific Railroad v. Artist, 60 Fed. 365, 368 (C. C.A. Sth, 1894).

There are in the United States 2,693 non-profit hospitals with 277,717 beds; 1,183 individual and partnership hospitals with 29,957 beds; 530 corporation hospitals (unrestricted as to profit) with 28,085 beds; 1,722 governmental hospitals with 788,749 beds. Industrial hospitals are listed as 36 in number with 2,835 beds but no indiention is given as to ownership. Aarericax Miedical Assochation, Census of Hospitals (1937).

2. See MacEachern, Hosptial Organization and Alasagearest (1935) 156-159. 
staff was selected. ${ }^{3}$ This liability has been imposed for the negligence of medical agents both in performing acts demanding professional skill and acts requiring only lay competence. The oft-repeated rationale runs that private hospitals conducted for profit have the duty to use reasonable care in safeguarding a patient, and this duty is limited only by the capacity of the patient to provide for his own safety. ${ }^{4}$ For example, private profit hospitals have been held liable in cases ${ }^{5}$ which involve the burning of unconscious patients by hot water bottles, packs and poultices; ${ }^{b}$ errors in operating room technique including anesthetics, hypodermics and injections $;^{7}$ improper surgical and medical treatment $; 8$ self-inflicted injuries which might have been prevented by more constant attention to infants ${ }^{0}$ and insane and de-

3. Norwood Hospital v. Brown, 219 Ala. 445, 122 So. 411 (1929); Parrish v. Clark, 107 Fla. 598, 145 So. 848 (1933); Gilstrap v. Osteopathic Sanitarium Co., 224 Mo. App. 798, 24 S. W. (2d) 249 (1929); Malcolm v. Evangelical Lutheran Hospital Association, 107 Neb. 101, 185 N. W. 330 (1921) ; Jenkins v. Charlestown Genertil Hospital, 90 W. Va. 230, 110 S. E. 560 (1922). Contra: Kamps v. Crown Heights Hospital, 251 App. Div. 849, 296 N. Y. Supp. 776 (2d Dep't 1937).

4. See Robertson v. Charles B. Towns Hospital, 178 App. Div. 285, 287, 165 N. Y. Supp. 17, 18 (2d Dep't 1917) ; Hayhurst v. Boyd Hospital, 43 Idaho 661, 669, 254 Pac. 528, 529 (1927); Smith v. Simpson, 221 Mo. App. 550, 556, 288 S. W. 69, 72 (1926); Tulsa Hospital v. Juby, 73 Okla. 243, 247, 175 Pac. 519, 523 (1918) ; Hogan v. Clarksburg Hospital Co., 63 W. Va. 84, 89, 59 S. E. 943, 945 (1907).

5. An analysis of 55 malpractice cases representing 65 hospitals from 1928 to 1933 showed that $23 \%$ were for burns from hot water bottles, packs and poultices; $17.7 \%$ for errors in operating room technique including anesthetics, hypodermics and injections; $10 \%$ for self-inflicted injuries which might have been prevented by more constant attention to insane and delirious patients; $10 \%$ for self-inflicted injuries by sane patients due to a lack of attention; $12 \%$ for injuries from X-ray, violet-ray, diathermy; $7.4 \%$ for injuries in postnatal maternity cases; $2.4 \%$ for improper surgical dressings; $7.2 \%$ miscellaneous. See Martin, Professional Liability Insurance for Hospitals (1933) 7 BulL. Aarerican Hospital Association, no. 7, 10 at 14.

6. Meyer v. Hospital, 173 Cal. 156, 159 Pac. 436 (1916); Phillips v. Buffalo General Hospital, 239 N. Y. 188, 146 N. E. 199 (1924) ; Duke Sanitarium v. Hearn, 159 Okla. 1, 13 P. (2d) 183 (1932); Harber v. Gledhill, 60 Utah 391, 208 Pac. 1111 (1922).

7. Objects left in wound after operation: Payne v. Santa Barbara Cottage Hospital, 2 Cal. App. (2d) 270, 37 P. (2d) 1061 (1934); Armstrong v. Wallace, 37 P. (2d) 467, rehearing 8 Cal. App. (2d) 429, 47 P. (2d) 740 (1935) ; Penland v. French Broad Hospital, 199 N. C. 314, 154 S. E. 406 (1930). Negligent incision: Jeter v. DavisFischer Sanatorium, 28 Ga. App. 708, 113 S. E. 29 (1922). Hypodermatoclysis restilted in injury: Malcolm v. Evangelical Lutheran Hospital Association, 107 Neb. 101, 185 N. W. 330 (1921). Negligence in operating: Gilstrap v. Osteopathic Sanatorium Co., 224 Mo. App. 798, 24 S. W. (2d) 249 (1929).

8. Parrish v. Clark, $107 \mathrm{Fla}$. 598, 145 So. $\$ 48$ (1933) (saline solution injected though having a noticeably ill effect).

9. See Maxie v. Laurel General Hospital, 130 Miss. 246, 248, 93 So. 817 (1922); Roche v. St. John's Riverside Hospital, 96 Misc. 289, 291, 160 N. Y. Supp. 401, 402 (Sup. Ct. 1916). 
lirious patients $;{ }^{10}$ and negligently maintained premises directly contributing to the injury of patients. ${ }^{11}$ Maintaining safe premises and guarding mentally irresponsible patients require only lay capacity and hence fall reasonably within the doctrine of respandcat supcrior. But the other enumerated defalcations are hardly within the control of hospitals, for they may be due to mistakes in medical judgment made by carefully selected physicians and nurses who are employed to practice their profession according to their own discretion. ${ }^{12}$ This consideration has led some of the New York courts to reject the doctrine that a private hospital operated for profit is liable for the torts of its medical staff no matter how carefully selected and to limit liability to cases of negligently chosen personnel. ${ }^{13}$ Hospitals do not practice medicine through agents, it is said, but rather are places where professional practitioners can give medical treatment to patients. ${ }^{14}$ Of course, hospitals can be required to use reasonable care and diligence in selecting staff physicians and nurses, ${ }^{15}$ for the hospital may control the quality of medical service rendered on its premises by exercising the privilege of appointing physicians, surgeons and nurses to its resident and visiting staffs, and by extending the use of the hospital premises to the courtesy staff. ${ }^{16}$

10. Durfee v. Dorr, 123 Ark. 542, 186 S. IV. 62 (1916); Hawthorne v. Blythewood, 118 Conn. 617, 174 At1. 81 (1934); Hignite's Administratrix v. Louisville Neuropathic Sanatorium, 223 Ky. 497, 2 S. WV. (2d) 407 (1928); Smith v. Simpson, 221 MIo. App. 550, 288 S. W. 69 (1926); Mraki v. Murray Hospital, 91 Afont. 251, 7 P. (2d) 223 (1932) ; Wetzel v. Omaha Maternity Association, 96 Neb. 636, 148 N. W. 582 (1914); Hogan v. Hospital Co., 63 W. Va. 84, 59 S. E. 943 (1907).

11. Baker v. Board of Trustees of Leland Stanford University, 133 Cal. App. 243, 23 P. (2d) 1071 (1933) (insulation on light switch broken and patient shocked); Tulsa Hospital Association v. Juby, 73 Okla. 243, 175 Pac. 519 (1918) (roof leaked on patient after operation). But cf. Robinson v. Crotwell, 175 Ala. 194, 57 So. 23 (1911) (physician operating private hospital for profit not responsible for failure to furnish adequate place for patient's surgeon to operate, but surgeon held responsible).

12. See Schloendorff v. N. Y. Hospital, 211 N. Y. 125, 131, 105 N. E. 92,94 (1914).

13. This is the present rule in the lower courts of New York. The New York Court of Appeals has not discussed the rule directly, though apparently it grew out of a dictum in one of the Court of Appeals opinions. Mfatter of Renouf $v$. New Yorls Central R. R., 254 N. Y. 349, 351, 173 N. E. 218, 219 (1930) (employer's liability case). See Mills v. Society of New York Hospital, 242 App. Div. 245, 274 N. Y. Supp. 233 (2d Dep't 1934), aff'd without opinion 270 N. Y. 594, 1 N. E. (2d) 346; Hendriclsson v. Hodkin, 250 App. Div. 619, 294 N. Y. Supp. 982 (2d Dep't 1937), rev'd on ofher grounds, 276 N. Y. 252, 11 N. E. (2d) S99; Kamps v. Crown Heights Hospital, 251 App. Div. 849, 296 N. Y. Supp. 776 (2d Dep’t 1937).

14. See Daly's Astoria Sanitarium, 161 Misc. 716, 719, 291 N. Y. Supp. 1005, 1009 (City Ct., 1936) ; cf. Mills v. Society of New York Hospital, 242 App. Div. 245, 274 N. Y. Supp. 233 (2d Dep't 1934).

15. See note 13 , stipra.

16. See Bachmeyer, The Hospital and the Medical Profession (1935) 9 BurL. Amrerican Hospital Assoctation, no. 7, 30 at 35; Walsh, The Responsibility of the Hospital Board of Trustecs for the Standards of Professional Performanee (Nov., 1936) Hospitals, 63; Hillyer v. St. Bartholomew's Hospital, 78 L. J. 958, 101 L. T. R. 368 (K. B., 1909). 
Even when indiscriminately applied, the doctrine of respondcat supcrior does not extend so far as to render the hospital liable for the torts of plyysicians and nurses who practice on hospital premises in the independent employment of private patients. ${ }^{17}$ However, the practical difficulties in determining when a medical employee is acting as the agent of a patient or his physician and when he is acting as the agent of the hospital have led to contflicting results. A staff nurse performing her duties in the operating room is deemed the agent of the surgeon performing the operation, ${ }^{18}$ while one carrying out a physician's orders in the patient's room during the physician's absence may be held to be acting for the hospital, ${ }^{10}$ or only for the physician. ${ }^{20}$ A hospital nurse who continues an obviously deleterious treat* ment renders the hospital liable even though the treatment had been ordered by the patient's own physician; $; 1$ and some courts have gone so far as to hold that a surgeon who is a principal officer and stockholder of a private hospital operated for profit may be working in the hospital as the agent of a patient rather than of the hospital. ${ }^{22}$ Since the hospital cannot control the countless discretionary acts and movements of physicians or nurses regardless of whether they are held to be agents of the hospital or of the patient, ${ }^{23}$ such distinctions seem both specious and arbitrary. Hence the minority doctrine, limiting the liability of private profit hospitals for the negligence of medical agents to cases where due care has not been used in their selection, seems more closely correlated to a feasible degree of control. ${ }^{24}$

17. Barfield v. South Highlands Infirmary, 191 Ala. 553, 68 So. 30 (1915); Simons v. Northern Pacific Railway Co., 94 Mont. 355, 22 P. (2d) 609 (1933); Gosncll v. Southern Railway Co., 202 N. C. 234, 162 S. E. 569 (1932); Holland v. Eugene Hospital, 127 Ore. 256, 270 Pac. 784 (1928).

18. Armstrong v. Wallace, 37 P. (2d) 467 (1934), rchearing 8 Cal. App. (2d) 429, 47 P. (2d) 740 (1935); Jordan v. Touro Infirmary, 123 So. 726 (La., 1922); Schloentdorff v. Society of New York Hospital, 211 N. Y. 125, 105 N. E. 92 (1914); Aderhold v. Bishop, 94 Okla. 203, 221 Pac. 752 (1923) (surgeon held liable for negligence of staff nurse during operation); Wolfe v. Mosler Safe Co., 139 App. Div. 848, 124 N. Y. Supp. 541 (4th Dep't 1910). See (1929) 4 Tulane L. Rev. 139.

19. Messina v. Societe Francaise de Bienfaissance, 170 So. 801 (La., 1936).

20. Simons v. Northern Pacific Railway Co., 94 Mont. 355, 22 P. (2d) 609 (1933); Randolph v. Oklahoma City General Hospital, 180 Okla. 513, 71 P. (2d) 607 (1937). But cf. Bowditch v. French Broad Hospital, 201 N. C. 168,159 S. E. 350 (1931) (patient by asking hospital nurse if he might leave hospital made her his own agent); Kuglich v. Fowle, 185 Wis. 124, 200 N. W. 648 (1924) (doctor discharged hospital of responsibility when he performed some of staff nurse's functions himself).

21. Parrish v. Clark, 107 Fla. 598, 145 So. 848 (1933); see Byrd v. Marion General Hospital, 202 N. C. 337, 341, 162 S. E. 738, 740 (1932).

22. Black v. Fischer, 30 Ga. App. 109, 117 S. E. 103 (1923); Stacy v. Williams, 253 Ky. 353, 69 S. W. (2d) 697 (1934).

23. See Taylor v. Flower Deaconess Home and Hospital, 104 Ohio St. 61, 73, 135 N. E. 287, 291 (1922).

24. See Ware v. Culp, 74 P. (2d) 283, 287 (Cal., 1937); Schloendorff v. New York Hospital, 211 N. Y. 125, 128, 105 N. E. 92, 94 (1914); In re Agnew's Will, 132 Misc. 466, 472, 230 N. Y. Supp. 519, 526 (Surr. Ct., 1928). 
That prevailing rules of hospital liability have little relation to practical supervision of medical activities on hospital premises is further indicated by the failure of the courts to require observance by the hospital of what would seem to be an obvious duty-to see that incompetent practitioners are not permitted the use of hospital facilities even under the heading of independent contractors. ${ }^{25}$ Inasmuch as the managers of private hospitals conducted for profit are better qualified to judge the competency of doctors and nurses than the ordinary layman, and are privileged to exclude anyone from practice on hospital premises, ${ }^{20}$ this duty would hardly be an onerous one. Such was the approach recently taken by the New York Court of Appeals. In the case of Hendrickson v. Hodkin, ${ }^{2 \pi}$ a private hospital operated for profit was held liable for permitting a layman to administer a so-called "cancer-cure" on its premises, despite the fact that the patient himself had retained the layman for the "cure." As Although the hospital had contracted only to provide room and board, the Court reasoned that its superintendent owed a duty to the patient to forbid a charlatan the privileges of hospital practice. ${ }^{29}$

A logical extension of the Hendrickson rule would hold hospitals to the duty of permitting only competent physicians, surgeons and nurses the use of hospital facilities, ${ }^{30}$ whether they practice there as regular members of the hospital staff or at the selection of the patient. Many practical difficulties,

25. See note 17, supra; 8 BuLI., Axrerrcan Hospiral Assoctution (1934) no. 1, 90.

26. Replogle v. Julia F. Burnham Hospital, 71 Ill. App. 246 (1896); Stevens v. Emergency Hospital, 142 MId. 526, 121 Atl. 475 (1923); Harris v. Thomas, 217 S. IV. 1068 (Tex. Civ. App., 1920); State ex rel. Wolfe v. LaCrosse Lutheran Hospital Association, 181 Wis. 33, 193 N. W. 994 (1923). To standardize the treatment given in a sanitarium a county medical association has the right to reject an osteopath as a member. Gregg v. Miassachusetts Aredical Society, 111 MIass, 185, 15 Am. Rep. 24 (1872).

27. 276 N. Y. 252, 11 N. E. (2d) 899 (1937).

28. The patient was the victim of a tort at the hands of the layman. N. Y. EovenTION LAw no. 1263, subd. 6. Brown v. Shyne, 242 N. Y. 176, 151 N. E. 197 (1926). The fact that the plaintiff retained the layman to commit a misdemeanor was not a bar to his right of action, for the parties were not in pari delicto. Bolivar v. Mronnat, 232 App. Div. 33, 248 N. Y. Supp. 722 (4th Dep't 1931).

29. Liability could have been founded on the ground that the staff nurse and internes were negligent in continuing an obviously deleterious treatment for some time. Parrish v. Clark, 107 Fla. 598, 145 So. 848 (1933); see Byrd v. Mfarion General Hospital, 202 N. C. 337, 341, 162 S. E. 738, 740 (1932).

30. Hospitals are liable if they knowingly permit their facilities to be used for unlawful purposes. See Schloendorff v. New York Hospital, 211 N. Y. 125, 125, 134, 105 N. E. 92, 95 (1914) (a charitable hospital would be liable if it permitted its facilities to be used for an unauthorized and therefore illegal operation on a patient). Compare Hasselbach v. Mount Sinai Hospital, 173 App. Div. 89, 159 N. Y. Supp. 376 (1st Dep't 1916) with Grawunder v. Beth Israel Hospital Association, 242 App. Div. 56, 272 N. Y. Supp. 171 (2d Dep't 1934), aff'd 266 N. Y. 605, 195 N. E 221 (1934) (performance of an unlawful autopsy on a body committed to the exclusive care of a hospital). 
however, may be encountered in adopting a standard of admittance by which the conduct of the institution may be judged. Suggested criteria ${ }^{31}$ are graduation from a recognized school of medicine, possession of a license to practice medicine in the state, interneship of at least one year in an approved hospital, ${ }^{32}$ and a reputation of being an ethical and competent physician. Specialists should be required to have had sufficient training and experience to warrant their recognition by the national society or examining board representing their specialty. Similar requirements might be adopted for internes and nurses.

Charitable hospitals have traditionally been favored with a broader scope of immunity than private hospitals conducted for profit. ${ }^{33}$ According to the great majority of cases, they are not liable for the torts of staff physicians, surgeons and nurses as long as reasonable care has been used in their selection. ${ }^{34}$ This result has been justified on the ground that the beneficiary of a charity impliedly waives his right to sue in tort for the injuries negligently caused by the carefully selected agents of his benefactor. ${ }^{35}$ Moreover, by means of the so-called trust fund theory, immunity has often been ex-

31. MacEachern, Hospital Organization and Management (1935) 144-5; MacEachern, Two Decades of Hospital Standardization (1935) 9 Bull., American Hospital Assoctation, no. 10,32 at $34,38$.

32. The Council on Medical Education and Hospitals of the American Medical Association and the Hospital Department of the Canadian Medical Association malic up the approved list of hospitals for internes. See MacEnchern, Hospital OnanniZATION AND MANAGEMENT (1935) 144.

33. However, charitable hospitals have been held liable to non-beneficiaries for the torts of their non-medical agents. Loeffer v. Trustees of Sheppard and Enoch Pratt Hospital, 130 Md. 265, 100 Atl. 301 (1917) (fireman injured through defective condition of fire escape); Hordern v. Salvation Army, 199 N. Y. 233, 92 N. E. 626 (1910) (journeyman mechanic injured on the premises while making boiler repairs); Murtha v. New York Homeopathic Medical College, 228 N. Y. 183, 126 N. E. 722 (1020) (ambulance negligently collided with a taxicab); Johnsen v. Staten Island Hospital, 246 App. Div. 638, 283 N. Y. Supp. 664 (2d Dep't 1935), aff'd without opinion, 265 N. Y. 658,193 N. E. 432 , aff'd on rehearing, 271 N. Y. 519, 2 N. E. (2d) 674 (1936) (visitor to hospital injured by torn floor). See Hayt, Hospital Liability for Negligence (Dec. 1937) Hospitals, 90 at $91,92$.

34. England v. Hospital of the Good Samaritan, 16 Cal. App. (2d) 640, 61 P. (2d) 48 (1936); Hawthorne v. Blythewood, 118 Conn. 617, 174 At1. 81 (1934) ; Mikota v. Sister of Mercy \& Mercy Hospital, 183 Iowa 1378, 168 N. W. 219 (1918) ; Rudy v. Lakeside Hospital, 115 Ohio St. 539, 155 N. E. 126 (1926); Bise v. St. Luke's Hospital, 181 Wash. 269, 43 P. (2d) 4 (1935). Contra: Mulliner v. Evangelisher Diakonniessenverein, 144 Minn. 392, 175 N. W. 699 (1920) (Hospital not immune for negligence in selecting employees, nor for their negligence if carefully selected).

35. See Powers v. Massachusetts Homeopathic Hospital, 109 Fed. 294, 304 (C. C. A. 1st, 1901) ("If a suffering man avails himself of their charity, he takes the risk of malpractice, if their charitable agents have been carefully selected."); Baker v. Trustees of Leland Stanford University, 133 Cal. App. 243, 245, 23 P. (2d) 1071, 1072 (1933); Armstrong v. Wallace, 37 P. (2d) 467, 468 (1934), reltcaring 8 Cal. App. (2d) 420, 433,47 P. (2d) 740,742 (1935). 
tended to include even negligence in such administrative acts as maintaining safe premises and selecting the medical and nursing staffs with care. ${ }^{3 B}$ Scant justification can be found in the usual reasoning of this theory that legal responsibility for the careful selection of hospital staffs would dissipate trust funds donated for charitable purposes, thereby contravening the wishes of donors as well as discouraging further gifts. ${ }^{37}$ On the contrary, if the governing body is permitted to employ those who are unskilled and incompetent, charitable funds may be diverted from their true purpose and become a menace rather than an aid to intended beneficiaries. ${ }^{38}$ Likewise, the implied waiver doctrine has been so vulnerable to common sense logic $\mathrm{i}^{39}$ that many courts have either simply declared that the doctrine of respondeat superior is inapplicable to the relationship between a charitable hospital and its medical and nursing staffs, ${ }^{40}$ or have taken refuge in the comfortable

36. Parks v. Northwestern University, 218 IIl. 381, 75 N. E. 991 (1905); Roosen v. Peter Bent Brigham Hospital, 235 Mass. 66, 126 N. E. 392 (1920); Downes v. Harper Hospital, 101 Mich. 555, 60 N. W. 42 (1894); Nicholas v. Evangelical Deaconess Home \& Hospital, 281 Mo. 182, 219 S. W. 643 (1920). But of. Tucker v. Mobile Infirmary Association, 191 Ala. 572, 68 So. 4 (1915); Glavin v. Rhode Island Hospital, 12 R. I. 411, 34 Am. Rep. 675 (1875) (modified by statute, R. I. Geserni Laws (1909) c. 213, \#38); Basabo v. Salvation Army, 35 R. I. 22, 85 Atl. 120 (1912) (Charitable hospital liable for the negligence of its servants at least to paying patients); MrcLeod v. St. Thomas Hospital, 170 Tenn. 423, 95 S. W. (2d) 917 (1936). Courts relying on other than the trust fund theory hold charitable hospitals liable for breach of express contracts to furnish skillful medical care. See (1921) 6 Coss. L. Q. 184-7. Armstrong v. Wesley Hospital, 170 Ill. App. 81 (1912); Roche v. St. John's Riverside Hospital, 96 Misc. 289, 160 N. Y. Supp. 401 (Sup. Ct., 1916). But of. Powers v. Massachusetts Homeopathic Hospital, 109 Fed. 294, 303 (C.C. A. 1st, 1901) (contract for careful service in a charitable hospital would be slira zires).

37. See note 36, supra. The trust fund theory originated in the English decision of Heriot's Hospital v. Ross, 12 Clark \& F. 507 (1846). For a defense of this doctrine and a criticism of the "waiver" and "respondeat superior" theories see MicCaskill, Respondeat Superior as Applicd in New York to Quasi Public and Elcemosynary Corporations (1920) 5 CoRN. L. Q. 409, (1921) 6 CoRs. L. Q. 36 . Strangely enough, the Massachusetts court has held that when a charitable hospital sued for money due for board and room the defendant could counter-claim for negligence to question worth of services rendered. Beverly Hospital v. Early, 197 N. E. 641 (Mrass., 1935).

38. See Hoke v. Glenn, 167 N. C. 594, 597, 83 S. E. 807,809 (1914). But see MfcCaskill, supra note 37, (1921) 6 CoRs. L. Q. at 81.

39. "The doctrine of implied waiver is logically weak It rests on the patent fiction that the patient has relinquished a known right by coming to the hospital for treatment." Phillips v. Buffalo General Hospital, 239 N.Y. 18S, 189, 146 N.E. 199, 200 (1924); Sheehan v. North Country Community Hospital, 273 N.Y. 163, 7 N. E. (2d) 28 (1937).

40. See Hearns v. Waterbury Hospital, 66 Conn. 98, 126, 33 Atl. 595, 604 (1895); Bernstein v. Beth Israel Hospital, 236 N. Y. 268, 270, 140 N. E. 694 (1923) ("Such a hospital undertakes not to heal or attempt to heal through the agency of others, but merely to supply others who will heal or attempt to heal on their own responsibility:"); Morrison v. Henke, 165 Wis. 166, 170, 160 N. W. 173, 175 (1916). 
vagueness of the proposition that it is against the best interests of the public to hold charitable hospitals liable for the negligence of their medical agents.41

The difficulties which many courts have experienced in ascertaining whether a particular hospital is charitable or conducted for profit attest the un* soundness of attempting to differentiate between the two for purposes of tort liability. ${ }^{42}$ Even if the general character of a hospital has been established as charitable, any distinction seems tenuous when the medical agent of a charitable hospital negligently injures a paying patient. Some courts have treated the paying patient in much the same fashion as the patient of a hospital conducted for profit, and have allowed him to recover so long as the trust fund itself is not dissipated by his claim ${ }^{43}$ other courts have forbidden recourse against the hospital on the ground that the patient was the beneficiary of a charity even though he paid for his medical services. ${ }^{44}$ Arguments similar to those advanced in the case of private hospitals can be atdvanced for refusing to apply the doctrine of respondeat superior. But since both charitable and profit-run hospitals are equally privileged to select their resident and courtesy staffs, ${ }^{45}$ there seems to be little reason for excusing

41. Southern Methodist Hospital \& Sanatorium of Tucson v. Wilson, 45 Ariz. 507, 46 P. (2d) 118 (1935) ; Shane v. Hospital of the Good Samaritan, 2 Cal. App. (2d) 334, 37 P. (2d) 1066 (1934); Cashman v. Meriden Hospital, 117 Conn. 585, 169 Atl. 915 (1933) ; D'Amato v. Orange Memorial Hospital, 101 N. J. L. 61, 127 Atl. 340 (1925); Lakeside Hospital v. Kovar, 131 Ohio St. 333, 2 N. E. (2d) 857 (1936) ; Roberts v. Ohio Valley General Hospital, 98 W. Va. 476, 127 S. E. 318 (1925).

42. Courts are often forced to examine the articles of incorporation and the financial records of a hospital to ascertain whether it is charitable or conducted for profit. Southern Methodist Hospital \& Sanitarium v. Wilson, 45 Ariz. 507, 46 P. (2d) 118 (1935); Stewart v. California Medical Association, 178 Cal. 418, 176 Pac. 46 (191S) (where despite of articles of incorporation a hospital is in fact conducted for profit, it is neither charitable nor exempt) ; Hamilton v. Corvallis General Hospital Association, 146 Ore. 168,30 P. (2d) 9 (1934).

43. Morton v. Savannah Hospital, 148 Ga. 438, 96 S. E. 887 (1918); Gamble v. Vanderbilt University, 138 Tenn. 616, 200 S. W. 510 (1918) ; McInerny v. St. Luke's Hospital Association, 122 Minn. 10, 16, 141 N.W. 837, 840 (1913) (charitable hospital liable for breach of non-delegable duty to put guards on machinery up to amount noncharity patients paid in); Cf. England v. Hospital of the Good Samaritan, 16 Cal. App. (2d) 640, 61 P. (2d) 48 (1936); Tucker v. Mobile Infirmary Association, 191 Ala. 572,68 So. 4 (1915).

44. St. Vincent's Hospital v. Stine, 195 Ind. 350, 144 N. E. 537 (1924); Jensen v. Maine Eye and Ear-Infirmary, 107 Me. 408, 78 At1. 898 (1910); Taylor v. Flower Deaconess Hospital, 104 Ohio St. 61, 135 N. E. 287 (1922); Lindler v. Columbia Hospital, 98 S. C. 25, 81 S. E. 512 (1914); Wharton v. Warner, 75 Wash. 470, 135 Pac. 235 (1913) ; Roberts v. Ohio Valley General Hospital, 98 W. Va. 476, 127 S. E. 318 (1925) ; Bishop Randall Hospital v. Hartley, 24 Wyo. 408, 160 Pac. 385 (1916).

45. Exemptions from "liability should be surrounded by such safeguards as will prevent the neglect of a duty which the hospital can and should perform . . . it can and should exercise care to see that only careful and competent servants minister to stricken patients who are within its walls." Taylor v. Flower Deaconess Hospital, 104 Ohio St. 61, 73, 135 N. E. 287, 291 (1922). 
the former from legal responsibility for the careful selection of those physicians and nurses who are allowed hospital privileges.

In common with other governmental agencies, public hospitals are generally liable for the torts of their servants only when the state has voluntarily assumed such liability, ${ }^{46}$ except in the relatively few instances where courts have held that maintenance of hospitals is not a governmental function. ${ }^{47}$ Since most states have not consented to being sued by citizens, their hospitals are completely without legal responsibilities. ${ }^{48}$ In addition to the immunity resulting from this special legal status, other barriers to liability are likely to arise in those states which provide by law that any licensed local physician must be admitted to practice in the local public hospitals. ${ }^{.0}$ Clearly it would be unreasonable to hold a public hospital even morally responsible for lack of care in admitting doctors and nurses to hospital privileges if the hospital is compelled by statute to open its staff to all those entitled to practice in any given community.50 Yet, in some cases governing bodies have been able to maintain standards, notwithstanding such laws, by strict supervision over hospital practice; in others, the attempt has been made to bar the incompetent from the hospital.51 State courts have, on several occasions, approved the action of the hospital in excluding unqualified practitioners, and the Supreme Court has ruled that a city has the right to bar a licensed osteopath from practice in a local public hospital. ${ }^{53} \mathrm{Mr}$. Justice Stone, speaking for the Court, said that a regulation could not be called unreasonable

46. For a general discussion of the theories of governmental immunity, see Borchard, Government Responsibility in Tort (1924) 34 Y ALE L. J. 129, 229, (1926) 36 YALE L. J. 1, 757, 1039, (1928) 28 CoL. L. REv. 577, 734.

47. City of Shawnee v. Roush, 101 Okla. 60, 223 Pac. 354 (1924); Borwege v. City of Owatonna, 190 Minn. 394, 251 N. W. 915 (1933). These eases suggest the possibility of evading the statutory immunity in cases of flagrant negligence by declaring that the hospital was failing to perform a governmental function. But the natural reluctance to set such a precedent would probably limit the use of such a device to exceptional cases.

48. Watson v. Atlanta, $136 \mathrm{Ga} .370,71$ S. E. 664 (1911); Tolleison r. City of Ottawa, 228 Ill. 134, 81 N. E. 823 (1907) ; Butler v. Kansas City, 97 Kan. 239, 155 Pac 12 (1916); Zachert v. City of Louisville, $214 \mathrm{Ky} .132,282 \mathrm{~S} . \mathrm{Wr} .1071$ (1926); City of McAllen v. Gartman, 81 S. W. (2d) 147 (Tex Civ. App., 1935) (full collection of governmental hospital cases at 149).

49. See e.g., NEv. CodrpIred Laws (Hillyer, 1929) \$2235. "In the management of such public hospital (county) no discrimination shall be made against practitioners of any regular school of medicine and surgery recognized by the laws of Nevada, and all such regular practitioners shall have equal privileges in treating patients in said hospital."

50. See Lapp, The Liability of the Hospital (1922) 24 Trassactro:rs, Asrericar: Míentcai Assoctation, 143 at 147.

51. See MicEacherd, Hospital Organization and alasiaguresti (1935) 147.

52. See (1929) \& TENN. L. REv. 58.

53. Hayman v. Galveston, 273 U. S. 414 (1927). But cf. Henderson v. City of Knoxville, 157 Tenn. 477, 9 S. W. (2d) 697 (1928) (Court ordered reinstatement to practice in city hospital of physician found violating medical ethics but not the State Medical Code). 
if its purpose was to exclude from hospital practice the devotees of some of the numerous systems or methods of treating disease authorized to practice in the state. ${ }^{54}$ In the states where the legislatures and the courts have not adopted such a view, patients in public hospitals will have to continue . to rely on their own ability to select qualified doctors and nurses.

Most courts carry over the standard rules of hospital liability to industrial hospitals built by employers for employees, the pivotal question being whether the particular hospital is to be labelled charitable or profit-maling. An employer who contracts with his employees to furnish medical care or derives any type of profit from the payroll contributions of the employees to the hospital has usually been held liable for all the negligent acts of his medical agents. 55 Yet in many cases, employers maintaining similar hospitals, perhaps with some assistance from employee contributions, have shared the immunity of charitable hospitals if due care was used in the selection of the doctors and nurses. ${ }^{58}$ There is some analogy between a non-profit, incorporated industrial hospital partially maintained by employees for their own benefit and the cooperative hospitals which may become a feature of socialized medicine. ${ }^{57}$ Since the criterion in dealing with incorporated associations seems to be whether or not they are operated for profit, pitals may conveniently be likened to the incorporated hospital association supported by employees and thus not liable for the torts of carefully selected medical agents.

This survey of existing rules of hospital liability suggests the need for formulating a more comprehensive, uniform rule which will assure qualified

54. Tex. Const. Art. XVI, §31, Tex. Ans. Rev. Civ. Stat. (Vernon, 1925) art. $4501,4503,4510$.

55. Sloss-Sheffield Steel \& Iron Co. v. Taylor, 16 Ala. App. 241,77 So. 79 (1917) (contract to furnish medical attention); Phillips v. St. Louis \& Santa Fe Ry., 211 Mo. 419, 111 S. W. 109 (1908); Texas \& Pacific Coal Co. v. Connaughton, 20 Tex. Civ. App. 642, 50 S.W. 173 (1899) (profits from hospital fund went to the employer); Sawdey v. Spokane Falls \& Northern Ry., 30 Wash. 349, 70 Pac. 972 (1902) (liable if medical service provided for in contract of employment); Mueller v. Winston Brothers Co., 165 Wash. 130, 4 P. (2d) 854 (1931) (employer liable as he received a benefit though not any profit from his employee hospital).

56. Union Pacific R. R. v. Artist, 60 Fed. 365 (C. C. A. Sth, 1894); Parsons v. Yolande Coal and Coke Co., 206 Ala. 642, 91 So. 493 (1921); Arkansas Midland R. K. v. Pearson, 98 Ark. 399, 135 S. W. 917 (1911) (employees did not contemplate that their contributions would be used to meet tort claims); Nicholson v. Atchison, T. \& S. F. Hospital Association, 97 Kan. 480, 155 Pac. 920 (1916); Illinois Central R. R. v. Buchanan, $126 \mathrm{Ky} .288,103$ S. W. 272 (1907) (incidental benefit to the employer does not make it liable); James v. Yazoo \& Miss. Valley R. R., 153 Miss. 776, 121 So. 819 (1929) ; Wells v. Ferry, 57 Wash. 658, 107 Pac. 869 (1910) (no express contract and no profit to employer). In most of these cases it was held that the employer must use due care in the selection of the medical staff.

57. See (1938) 47 YaLE L. J. 1193.

58. Nicholson v. Atchison, T. \& S. F. Hospital Association, 97 Kan. 480, 155 Pac. 920 (1916). But see Hulbert, Legal Phases of Cooperntive Associations (1929) 96; Andreen v. Escondido Citrus Union, 93 Cal. App. 182, 269 Pac. 556 (1928) (liable for negligence in fumigating members' orchard). 
medical practitioners in hospitals without discouraging the building and maintenance of institutions, whether supported by patients or by gifts. Such a rule would require of all hospitals-charitable and private profit-reasonable care in providing safe premises, in protecting infants and insane and delirious patients; and in permitting only competent physicians, surgeons and nurses the use of hospital facilities; but would exempt all hospitals from liability for the errors in medical judgment or negligent acts of qualified doctors and nurses.

The question may be raised why hospitals should not be held strictly liable for negligence in giving medical attention, thereby forcing them to distribute the financial burden through insurance against malpractice. ${ }^{50}$ There are, however, several convincing arguments against such a policy. A patient injured through negligence can always recover a judgment against the actual tortfeasor. ${ }^{60}$ Most hospitals, being more anxious to settle suits than to risk adverse publicity, are peculiarly subject to spurious suits and if complete liability prevailed this burden would probably become intolerable. ${ }^{01}$ Also, at the present time hospital insurance is increasingly difficult to obtain, particularly in states reputed to have high rates of malpractice recovery. ${ }^{62}$ Finally, adequate hospitalization would probably be considerably deterred by the oppressive addition to operating costs necessitated by insurance coverage for all medical agents employed by a hospital. ${ }^{.3}$

59. Charitable hospitals carrying such insurance are nonetheless immune from liability. Mississippi Baptist Hospital v. Moore, 156 Mriss. 676, 126 So. 465 (1930); see Knox County Tuberculosis Sanitarium Inc. v. MIoss, 5 Tenn. App. 589, 591 (1927).

60. According to statistics, malpractice suits against doctors and hospitals increased $25 \%$ between 1923 and 1933, and at that time the increase was continuing. MIartin, Professional Liability Insurance for Hospitals (1933) 7 BuLL. Asnenscas Hospirsc Assoctation, no. 7, 10.

61. See Goodnow \& Lodge, Hospital Accidents (1911) 12 Asresican Hosprtar Assoctation 256 at 277; Watson, Hospital Insurance (1923) 25 Arsencisi Hospiral Assoctation 350 at 351; also 38 id. at 592 (1936); 39 id. at 920 (1937).

62. Communication to the Yale Law Jourasal from the American Hospital Association, September 18, 1938.

63. Different rates of insurance premiums prevail throughout the country, since they are based on the losses and expenses sustained in a given territory over a period of years. Communication to the Yale LAw Journal from the United States Fidelity and Guaranty Company, September 21, 1938. The following table is an example: The policy allows $\$ 5,000$ for an accident and $\$ 15,000$ as a total claim during the policy term. The bed charge varies from $\$ .75$ to $\$ 1.50$ depending on the number of beds for charitable hospitals; $\$ 1$ to $\$ 2$ for part charity and part pay hospitals; $\$ 1.50$ to $\$ 3$. for pay only hospitals. A rate of $\$ 10$ is charged for each graduate licensed physician, surgeon, graduate or under-graduate interne; $\$ 15$ for each physician using $X-$ ray for diagnosis or treatment; $\$ 15$ if radium is used and is the property of the hospital; $\$ 5$ for each technician giving or assisting in giving $\mathrm{X}$-ray or radium treatments, each laboratory technician, pharmacist. 63 Buld, Insurance Producers (1930) sec. 5. Lloyd's is said to be writing a special policy at a very low rate at the present time but it is limited to hospitals approved by the American College of Surgeons. Communication to the YAlE IAW Journai from The Ayrerican Hospital Assoclation, September 21, 1938. 